\title{
OBECNOŚĆ FILOZOFII A NAUKI SPOŁECZNE
}

\author{
Tadeusz Szawiel
}

Każda pojęciowość zakłada obecność tego, co filozoficzne i co wymaga uzasadnienia, jakiego nie jest w stanie dostarczyć nauka, ponieważ sama nauka już zakłada to, co ewentualnie miałoby zostać uzasadnione. Rodzaj dyskursu, który prowadzi do prezentacji takich uzasadnień, zaliczamy do sfery filozofii. Próba zbycia problemu przez wskazanie, że w naukach zasadniczy argument stanowi odwołanie do empirii, nie jest trafne. Nie istnieja przecież pojęcia „czysto empiryczne”. Przeciwstawienie „teoretyczny-empiryczny” ma swój sens, jest wygodną abstrakcją i uproszczeniem, ale już na gruncie konkretnej nauki i w jej ramach. To w ramach konkretnej teorii i jej założeń metodologicznych można sensownie odpowiedzieć na pytanie o to, co „liczy” się jako fakt empiryczny i jakie są jego sposoby badania. Dwa proste przykłady: dla teoretyka społeczeństwa obywatelskiego ważne jest członkostwo w dobrowolnych organizacjach i aktywność w nich, jednak dopiero teoria kapitału społecznego wprowadza nowy fakt empiryczny, różnicując dobrowolne organizacje o masowym członkostwie na takie, które kreują kapitał społeczny i takie, które go nie tworza. Teoria kapitału społecznego dostarcza również kryteriów, pozwalających zidentyfikować oba rodzaje masowych organizacji. Podobnie fizyka Arystotelesa operowała pojęciami ciała ziemskiego i ciała niebieskiego oraz pojęciem miejsca przynależnego ciału zgodnie z jego natura. W fizyce Newtona nie występują takie pojęcia, a zatem nie istnieja na jej gruncie odpowiadające im „fakty empiryczne”, jak „ciało ziemskie” czy „ciało niebieskie”; podobnie nie istnieje w jej ramach taki fakt, jak „przynależne ciału miejsce zgodne z jego istotą”.

Obecność filozofii w naukach (społecznych) można ujmować na wiele sposobów. Zasadniczą tezą tego tekstu jest stwierdzenie, że jej obecność ujawnia się w nich na zasadniczo dwóch poziomach. Jeden to poziom najogólniejszych - posługując się terminologią Thomasa

\footnotetext{
${ }^{1}$ Przekonują o tym krytyki spostrzeżenia zmysłowego, zwracające uwagę na to, że nie istnieje bezzałożeniowe, niczym nieuwarunkowane, ,,czyste” spostrzeżenie.
} 
Kuhna - paradygmatycznych założeń, wskazanie podstawowych pojęć, konstytuujących przedmiot, punkt widzenia lub podstawowy proces. Takie paradygmatyczne założenia, stanowiące najogólniejsze ramy pojęciowe, zapoczątkowują tradycje badawcze. Egzemplifikacje tego najogólniejszego poziomu stanowią: powstanie nowożytnej nauki (Galileusz, Newton), nowożytnej filozofii politycznej (Hobbes), oraz filozofii dziejów (Max Weber i Carl Schmitt). Dla tego rodzaju najogólniejszych, paradygmatycznych ram odniesienia charakterystyczna jest współpierwotność filozofii i nauki, co jako konsekwencja wyklucza możliwość planowania i kontroli „spotkania” filozofii z nauką.

Drugi poziom obecności filozofii ujawnia się w sytuacji praktyki badawczej wewnątrz konkretnej nauki. W naukach społecznych badacz pracujący w ramach konkretnej teorii i metodologii w zasadzie nie spotyka się z problemami, które domagają się filozoficznych rozstrzygnięć, ponieważ zostały one już dokonane, świadomie bądź nie, przez jego poprzedników. Problem obecności filozofii pojawia się wówczas, gdy teoria i metodologia przestają być skutecznym narzędziem lub gdy pewnego rodzaju dociekliwość i presja pytań badawczych wiedzie nas do punktu, w którym nie ma już odpowiedzi w ramach podejścia, którym się posługujemy. W obu typach sytuacji pojawia się miejsce na metarefleksję, rodzaj aktywności filozoficznej, która może być pomocna w przełamaniu impasu badawczego. W części drugiej analizuję na wybranych przykładach oba typy sytuacji.

W części trzeciej pracy odnoszę się do problemów praktycznych. To, na ile obecność filozofii może okazać się kreatywna, jest sprawą praktyki instytucjonalnej i intelektualnej. Podstawowy problem polega na wskazaniu granic, jakie napotykają świadome praktyki kształtowania obecności filozofii wobec nauk.

\section{/// 1.}

Pierwszy, najogólniejszy poziom obecności tego, co filozoficzne, wiąże się z powstaniem nowożytnej nauki. Martin Heidegger w swoim wykładzie Pytanie o rzecz. (Heidegger 2001: 74) zwraca uwage, że struktury myślenia i pojęciowości, będące podstawą nowożytnej nauki, nie są związane z jakimś jednym, konkretnym okresem. Pierwsze przejawy takiego myślenia pojawiaja się w XV w., w czasach późnej scholastyki. Jednak dopiero w XVII w. następuje przełom pod względem jasnego ujęcia nowego projektu $\mathrm{i}$ jego uzasadnienia. W pewnym sensie koniec tego procesu następuje wraz z opublikowaniem przez Newtona w latach 168687 Pbilosophiae naturalis principia mathematica. Jednak zasadniczego przełomu dokonał wcześniej Galileusz w opublikowanych w 1638 r. Discorsi, gdzie 
czytamy: „Mobile [...] mente concipio omni secluso impedimento - myślę sobie coś poruszającego się pozostawionego samemu sobie” . W tym określeniu pojawia się całkowicie nowe ujęcie ciała. Problem polega na tym, że takie ciało nie istnieje. Nie mogło być zatem rezultatem żadnej obserwacji ani nie mogło wyjść na jaw w żadnym eksperymencie (Heidegger 2001: 84)². Jak mogło się pojawić takie myślenie i nastawienie do przyrody? Heidegger zauważa: „To podstawowe określenie rzeczy nie jest ani dowolne, ani oczywiste. Dlatego potrzebna była długa walka, aby doprowadzić je do panowania. Potrzebna była zmiana sposobu podejścia do rzeczy wraz z uzyskaniem nowego sposobu myślenia” (Heidegger 2001: 85). Nacisk położony jest na zmiany w długim okresie, Heidegger upatruje ich poczattków w później scholastyce (koniec XV w.). Nie były one rezultatem żadnego świadomego zamiaru (stworzenia nowożytnej nauki!). W pewnym sensie do przełomu, tzn. do poziomu filozoficznej samoświadomości „nowy sposób myślenia” doprowadził Kartezjusz. To nowe myślenie znalazło pełny wyraz w mechanice klasycznej Newtona, a zatem pod koniec XVII w. Ale dopiero cały wiek później Kant przedstawił pełne filozoficzne uzasadnienie matematycznego projektu nowożytnego przyrodoznawstwa.

To wskazuje na ważną rzecz, kiedy rozpatrujemy wzajemne relacje między filozofia a naukami. Nie jest to relacja pomiędzy dwiema dobrze wyodrębnionymi całościami intelektualnymi, bo w momencie, kiedy Galileusz pisał swoje Discorsi nie było ani „tej” filozofii, ani „tej” nauki. W konsekwencji relacja ta nie może być ujmowana instrumentalnie. Wiedza filozoficzna nie może być rozumiana jako instrument pomocny w osiaganiu pewnego rodzaju rezultatów w nauce, stąd rady kierowane pod adresem naukowców, by sięgnęli do filozofii, są bezużyteczne. Po pierwsze to, co filozoficzne i to, co naukowe, jest współpierwotne. Po drugie, w okresach najbardziej produktywnych to, co filozoficzne, nie jest stematyzowane, nie jest „wiedza przedmiotową, ale operacyjna.

W refleksji społecznej (filozofii polityki, czy, jak powiedzielibyśmy dziś, w naukach społecznych) nowożytna struktura myślenia pojawia się w formie klasycznej u Hobbesa, dla którego teoretycznym punktem wyjścia jest jednostka, indywiduum w stanie natury (condition of nature). Z tej całkowicie nowej perspektywy Hobbes odpowiada na pytanie: jak możliwe jest społeczeństwo (civil society)? Odpowiedzia jest teoria umowy społecznej - przejścia od stanu natury do civil society. Podobnie jak dzieło Galileusza i Newtona, tak i dzieło Hobbesa nie wzięło się znikąd. Symptomów zmian można upatrywać w początkach XVI w. wraz z protestancką rewolucja religijna. Nowa perspektywa oznaczała odrzucenie klasycznej

\footnotetext{
${ }^{2}$ Heidegger (2001): ,Takiego ciała nie ma. Nie ma również żadnego eksperymentu, który kiedykolwiek mógłby doprowadzić do naocznego przedstawienia takiego ciała”.
} 
(Arystotelesowskiej) teorii polityki, zwrot od wspólnoty ku indywiduum³ Dwa aspekty religijnej rewolucji XVI w. maja znaczenie dla zmiany perspektywy. Po pierwsze, protestantyzm dowartościowal indywiduum poprzez eliminację kapłana jako pośrednika między jednostką a Bogiem (spowiedź bez pośrednictwa kapłana) oraz wyeliminowanie pośrednika (Kościoła jako instytucji rozstrzygającej poprawność interpretacji i strażnika tradycji, będącej źródłem rozumienia Pisma) między wiernym a Pismem Świętym. Bezpośrednia odpowiedzialność przed Bogiem i swoboda studiowania prawd wiary stanowiły dowartościowanie jednostki. Związany z tym wzrost roli indywidualnego sumienia sprawił, że jednostka przesunęła się ku centrum wiary. Po drugie, nowe zjawisko religijnych wojen domowych XVI i XVII w., które nie tylko pozbawiały bezpieczeństwa jednostki, ale wyniszczały wspólnoty polityczne. Oba problemy - indywiduum jako systematyczny punkt wyjścia (nieprzypadkowo pierwsza część Lewiatana nosi tytuł $O$ człowieku) oraz bezpieczeństwo jednostki i trwałości wspólnoty politycznej-podejmuje Hobbes w swojej filozofii społecznej. Warto dodać, że on sam był bardzo przejęty duchem nowożytnej nauki (wówczas: filozofii natury). W czasie podróży na kontynent spotkał się w 1635 r. z Galileuszem i jemu zawdzięczał intelektualną inspirację:

Zaczął [Hobbes] pojmować świat jak to sugerował Galileusz. W swojej surowej wersji prawa bezwładności Galileusz utrzymywał, że ruch, a nie spoczynek, jest naturalnym stanem ciał. Ciała poruszaja się, dopóki nie natrafią na przeszkody. Wszystko porusza się. Hobbes rozciagnął tę ideę na człowieka i społeczeństwo. I tak narodziła się jego wyobrażona idea: „życie nie jest niczym innym jak ruchem członków; bo czymże jest serce jak tylko sprężyna; a nerwy tylko wielką ilością sznurków; a stawy, wielością kół, nadająca ruch całości”. Nawet samo myślenie było tylko ruchem pewnej wewnętrznej substancji w głowie (Peters 1997: 9-10).

Ale to nie Galileuszowi zawdzięczał Hobbes ideę umowy społecznej, której podmiotami są indywidua, raczej metodę prezentacji argumentów na „sposób geometryczny”, co jednak miało drugorzędne znaczenie dla jego nauki społecznej, było jedynie danina złożoną duchowi epoki.

Hobbes był pierwszym wielkim myślicielem, dla którego procesy, które ujawniły się w XVI i XVII w., stały się wyzwaniem. Ich „rozpoznania” i „ujęcia w system pojęć” nie da się od siebie oddzielić. Element tego co filozoficzne - mente concipio - był zawsze zasadniczy w rozpoznaniu i ujęciu procesów, których wyjaśnienie jest celem teorii społecznej na najwyższym poziomie.

Weber widział te procesy i podciagał je pod pojęcie „racjonalizacji”. Dzięki temu pojęciu upatrywał w nich kierunkowe procesy, które swój

\footnotetext{
${ }^{3} \mathrm{~W}$ ujęciu klasycznym to wspólnota polityczna konstytuuje jednostki, natomiast w nowożytnym (teoriach umowy społecznej) to jednostki konstytuują wspólnotę polityczną.
} 
początek miały w starożytnej Grecji. Weber pyta: ,jaki splot okoliczności doprowadził do tego, że właśnie na glebie Zachodu i tylko tu wystapiły zjawiska kulturowe, które - przynajmniej w naszym mniemaniu - rozwinęły się w powszechnie obowiązującym, mającym uniwersalne znaczenie kierunku?" (Weber 1994: 1). We wszystkich zjawiskach, które Weber wymienia - racjonalny i uporządkowany system uprawiania nauki, teologia, prawo kanoniczne, racjonalna nauka prawa, racjonalna muzyka harmoniczna, zawodowy urzędnik i racjonalna biurokracja i „,najistotniejsza dla naszego losu potęga współczesnego życia - kapitalizm" - widzi on ten uniwersalny kierunek rozwoju: racjonalizację. „Chodzi o to - pisał Weber by rozpoznać szczególną specyfikę zachodniego, zwłaszcza współczesnego, racjonalizmu i wyjaśnić jego powstanie” (Weber 1994: 13). Można to nazwać weberowską filozofią dziejów: dzieje jako proces racjonalizacji, obejmujący wszystkie istotne zjawiska kulturowe.

$\mathrm{Na}$ najwyższym poziomie teorii społecznej procesy, które zaczęły się w XVI w., nadal są określane jako procesy racjonalizacji, sekularyzacji, modernizacji, a ich konsekwencje sa przedmiotem badań do dziś, by wspomnieć chociażby ostatnie prace Charlesa Taylora (Źródta podmiotowości i A Secular Age) (Taylor 2001, 2007).

Co najmniej od lat 80. przedmiotem intensywnego zainteresowania i recepcji stały się prace Carla Schmitta, które na innym materiale podejmuja ten sam temat przebiegu, sensu i konsekwencji procesów sekularyzacji ${ }^{4}$. Schmitt explicite podejmuje problematykę Webera. Pierwsze trzy rozdziały Teologii Politycznej ukazały się pt. Socjologia pojecia sunerenności a teologia polityczna w pracy zbiorowej Gtówne problemy socjologii. Ku pamięci Maxa Webera (Schmitt 1923)5. Zwłaszcza w trzecim rozdziale Teologii Politycznej Schmitt objaśnia, co rozumie przez „socjologię pojęcia”, także w odróżnieniu od Webera (Schmitt 2000: 66-68). Jacob Taubes w deklaracji Schmitta widzi bezpośrednią kontynuację dzieła Webera:

Jesteśmy świadomi, że nauka prawa jest zjawiskiem specyficznie europejskim. Nie jest jedynie praktyczną mądrością ani umiejętnością techniczna. Jest głęboko uwikłana w przygodę zachodniego racjonalizmu. Jej duch ma szlachetnych rodziców. Jej ojcem jest odrodzone prawo rzymskie, a matką rzymski kościół. Oddzielenie od matki dokonało się ostatecznie po wielu wiekach trudnych zmagań w epoce wojen wyznaniowych. Dziecko trzymało się ojca, prawa rzymskiego, i opuściło dom matki. Szukało nowego domu i znalazło go w państwie (Taubes 1987: 12-13) ${ }^{6}$. Schmitt sam nawiązuje bezpośrednio do motywu sekularyzacji mówiąc

\footnotetext{
${ }^{4} \mathrm{~W}$ świecie anglosaskim ważny był numer specjalny „Telos” (72) z lata 1987 roku zatytułowany: Carl Schmitt: Enemy or Foe?

${ }^{5}$ Stosunek Schmitta do socjologii Webera omawia R. Mehring (Mehring 2009: 124-129).

${ }^{6}$ Cytowany przez Taubesa fragment pochodzi z: (Schmitt 2002a: 69).
} 
o „epoce całego szeregu neutralizacji”, związanych z czterema stadiami europejskich dziejów: teologicznym, metafizycznym, moralnym, ekonomicznym i ostatnim, technicznym, na którym, jego zdaniem, kończy się epoka neutralizacji. Pierwsza i najważniejsza zmiana dokonała się w XVII w.: przejście od stadium teologicznego do stadium metafizycznego, związanego z rozwojem nowożytnej nauki: „zmiana ta aż po dziś dzień określiła kierunek, który musiał przybrać późniejszy rozwój”. Pojęcie neutralizacji odnosi się do istoty zmiany, którą był, zdaniem Schmitta, określający całe stulecia motyw dążenia do „sfery neutralnej”. XVI- i XVII-wieczne spory i wojny religijne doprowadziły do poszukiwania neutralnego obszaru, na którym możliwe byłoby porozumienie. Takim nowym obszarem okazały się „naturalne”" systemy teologii, metafizyki, moralności i prawa. Stary obszar tradycyjnej teologii został zneutralizowany przez to, że przestał być centralny, a na ,gruncie nowego centralnego obszaru miano nadzieję na znalezienie minimum porozumienia i wspólnych przesłanek umożliwiających bezpieczeństwo, oczywistość (Evideñ), porozumienie i pokój”. Problem jednak zdaniem Schmitta polega na tym, że odtąd Europejczycy przemieszczają się z jednego obszaru walki do nowego obszaru neutralnego, a ten nowy neutralny obszar natychmiast staje się nowym obszarem walki, zatem ponownie pojawia się konieczność szukania nowej sfery neutralnej. W XX w. takim neutralnym obszarem, „ostatecznie i absolutnie neutralnym", miała być technika (Schmitt 2002: 88-95). Schmitt argumentuje, że nadzieje łączone pod tym względem z techniką sa złudzeniem. Jest ona neutralna $\mathrm{w}$ innym sensie niż wszystkie poprzednie neutralne obszary. Technika jest zawsze instrumentem (lub bronia), która służy każdemu, kto się nią posłuży i w tym sensie nie jest neutralna („Technika nie jest w stanie dokonać niczego innego jak pokój lub wojnę wzmocnić, jest w równym stopniu zdolna do jednego jak i drugiego...”). Wraz ze sferą techniki dobiegł do końca zapoczątkowany w XVII w. proces neutralizacji. Schmitt uważał, że technika nie tworzy żadnego nowego neutralnego obszaru. Zafascynowanie i wiara w jej możliwości - co Schmitt określał mianem „religii techniczności” w odróżnieniu od samej techniki stanowi pewnego rodzaju okres przejściowy. Sądzil, że dopiero okaże się, „jaki rodzaj polityki jest wystarczająco silny, by posłużyć się techniką i jakie to rzeczywiście, na tym nowym gruncie, powstana grupowe krystalizacje przyjaciel-wróg" (Schmitt 2002: 94).

Schmitt zdawał sobie sprawę, jakiego rodzaju rozumienie dziejów kryje się za jego analizą procesu sekularyzacji jako procesu neutralizacji i odpolitycznienia. Przemiany, które zidentyfikował, były jednorazowym, niepowtarzalnym następowaniem po sobie „obszarów centralnych”. Nie

${ }^{7}$ Naturalne w sensie racjonalne. 
upatrywał tu działania żadnego ogólnego prawa ani żadnej dziejowej konieczności. Jak sam to wyraził:

Dzieje to nie przebieg naukowo-przyrodniczych, biologicznych lub jeszcze innych reguł i norm. Ich istotną i specyficzną treścia jest wydarzenie, które jeden jedyny raz wydarza się i nigdy się nie powtarza. Tu nie liczą się ani eksperymenty, ani funkcjonalizm, ani kontrfaktyczne okresy warunkowe w postaci sformułowań, co by się było wydarzyło, gdyby to czy tamto wydarzenie nie miało miejsca; np. gdyby Arabowie nie przegrali bitwy pod Poitiers, gdyby Kolumb nie odkrył Ameryki, gdyby Napoleon nie przegrał bitwy pod Waterloo lub jeszcze inne uchronie ${ }^{8}$. To wszystko nie ma sensu wobec niepowtarzalności dziejowych wydarzeń. Dziejowe wydarzenie dzieje się tylko raz i jego jedyność ulega unicestwieniu przez racjonalizm filozofii dziejów (Schmitt 2005: 851).

Podane tu przykłady teorii na najwyższym poziomie, teorii epokowych procesów społecznych wyraźnie wskazują że są one nierozerwalnie związane z opcjami filozoficznymi.

\section{$/ / / 2$.}

W jakich momentach pojawia się „potrzeba filozofii” na niższych poziomach badań społecznych? Przyjrzyjmy się dwóm przykładom, które pokazuja, kiedy analiza filozoficzna okazuje się produktywna.

\section{/// A.}

Pierwsza sytuacja wiąże się ze zmianą samoświadomości badawczej. Załóżmy, że przedmiotem naszych analiz jest tzw. religijność ludowa, rozumiana zazwyczaj jako religijność ,gorszego rodzaju” lub jako religijność co najmniej ułomna, gdzie obrzędowość, rytuał odgrywa bardzo dużą rolę?.

W charakterystykach religijności ludowej podkreśla się szczególnie dwie cechy: przeakcentowanie religii rytualnej i spetryfikowanie prawd wiary i zasad moralności. Rytualizm, obrzędowość, ubóstwo doktrynalne, brak religijnego życia wewnętrznego (Czarnowski 1958: 90) ${ }^{10}$ to najczęściej podnoszone atrybuty ludowej religijności. Przywiązanie do rytuału i obrzędu, dla niej charakterystyczne, prowokuje sądy o jej powierzchowności i bywa interpretowane jako przejaw jej słabości, zwłaszcza w sytuacji zmiany społecznej, zmiany warunków życia i mobilności.

Nie inaczej uważa Stefan Czarnowski:

Obrzędy stają się w ich oczach zespołem gestów i formuł potrzebnych i świętych, ale nie zawierających innej treści pojęciowej niż ta,

\footnotetext{
${ }^{8}$ Uchronia - w analogii do utopii oznacza czasokres, którego nie było - „Napoleon nie przegrał bitwy pod Waterloo" - nie było takiego czasookresu, bo nie było takiego wydarzenia.

${ }^{9}$ Fragment zaadaptowany z: Szawiel 2008.

${ }^{10}$ Czarnowski (1958): „Nie ma nigdy mowy o życiu religijnym wewnętrznym”.
} 
którą nadaje im codzienne życie chłopa rolnika. Zrozumiałe wydaje się przeto, że mimo iż akty religijne zajmuja w życiu ludu polskiego tak wiele miejsca, religia tego ludu jest tak niesłychanie uboga z punktu widzenia doktrynalnego.

I dalej:

Wyraża się to także w stosunku włościanina do zagadnienia osobistego życia religijnego i osobistego zbawienia. Wystarcza mu wiara w to, że go Jezus odkupił i że opiekuje się nim Matka Boska, on zaś sam łamać sobie głowy nie potrzebuje nad nauką prawd objawionych - to rzecz księży - aby tylko zachowywal starannie nakazy obrzędowe, aby uczęszczał na nabożeństwa, śpiewał w kościele, zdejmowat czapke $i$ żegnat sie przed krzyżem. [...] Jak dalece ten rytualizm jest zakorzeniony w ludzie polskim, dowodem opór stawiany przez lud ten wszelkim próbom najdrobniejszych nawet zmian w praktykach, bez względu na to, że są dozwolone przez powołaną do tego władzę kościelną (Czarnowski 1958: 96-97).

Obrzędowość i rytualizm pojmowane są także przez Czarnowskiego, jako niemal czysto zewnętrzne zachowanie, niezawierające religijnej treści pojęciowej. Załóżmy, że chcemy przedstawić inną perspektywę spojrzenia na ten aspekt religijności ludowej, która bynajmniej nie musi być rozumiana jako religijność ,gorszego rodzaju”. Czy rzeczywiście rytuał jest czymś zewnętrznym? Uwagi Ludwiga Wittgensteina mogą być pomocne:

U podstaw religijnego symbolu nie ma żadnego pržekonania. [...] Oprócz czynności, które by można nazwać zwierzęcymi, [...] ludzie wykonuja również czynności, które mają szczególny charakter i które mogłyby być nazwane rytualnymi. Jednak czymś nonsensownym byłoby twierdzenie, że charakterystyczną cechą tych czynności jest to, że są wynikiem błędnych poglądów na fizykę rzeczy. [...] Przeciwnie, to, co znamionuje działania rytualne, nie jest wcale żadnym poglądem czy przekonaniem, słusznym czy też fałszywym, choć przekonanie - wiara - samo może być rytualne, może należeć do rytuału (Wittgenstein 1998: 20-21).

Objaśniając swoje rozumowanie, Wittgenstein odwołuje się do następującego przykładu:

Pomyślmy o tym, jak po śmierci Schuberta brat pociął jego partytury na niewielkie kawałki i rozdał ulubionym uczniom fragmenty zawierające pojedyncze takty. Działanie to jest dla nas tak samo zrozumiałe jako znak czci, jak postępowanie odmienne - pozostawienie partytur nietkniętych, niedostępnych nikomu. A jeśliby brat Schuberta spalił partytury, byłoby to również zrozumiałe jako wyraz czci (Wittgenstein 1998: 17).

Za działaniami brata nie kryje się żaden pogląd na temat oddziaływania partytury na uczniów czy związku między partyturą a uczniami (które to poglądy mogłyby być prawdziwe lub fałszywe). Sa to działania - a tym samym nie przysługuje im kwalifikacja w kategoriach prawdy i fałszu - będące wyrazem czci dla brata. Nie są one ani wyrazem, ani ilustracja jakichś treści. W nich, jeżeli można tak powiedzieć, ucieleśniła się cześć 
dla brata. Podobnie jeżeli w momencie ogłoszenia przez sąd wyroku pada wezwanie „proszę wstać”, to za tym rytualnym zachowaniem nie kryje się żadne przekonanie typu: jeżeli nie wstaniemy, to zmniejszy się szansa na uznanie przez nas wyroku za sprawiedliwy bądź prawomocny. Parafrazując Wittgensteina (Wittgenstein 1998: 14) ${ }^{11}$, można powiedzieć, że powstanie jest wyrazem majestatu sądu. Powstanie i majestat stanowia jedno, podobnie jak „oddanie czci bratu” i „rozdanie pociętych partytur”.

Objaśniając rytuał (ceremonię) Wittgenstein pisze:

Nie może istnieć wystarczająca praysczynna, to znaczy w ogóle nie istnieje żadna przyczyna, która pewnym rasom ludzkim kazałaby czcić drzewo dębu, lecz to tylko, że one i dąb zjednoczone były we wspólnocie życia, a zatem nie z wyboru, lecz stąd, że zrodziły się razem niczym pies i pchła. (Gdyby pchły stworzyły jakiśs rytuał, odnosiłby się on do psa). Można powiedzieć, że to nie ich zjednoczenie (dębu i człowieka), lecz ich, w pewnym sensie, oddzielenie, spowodowało te rytuały.

Bowiem przebudzenie się intelektu następuje wraz z oddzieleniem od pierwotnej gleby, pierwotnego podłoża życia. (Powstanie wyboru). (Formą budzącego się ducha jest oddawanie czci) (Wittgenstein 1998: 30).

To nie są rezultaty empirycznej obserwacji, ale próba zrozumienia, kim jest człowiek i czym jest życie. Można to nazwać rehabilitacja ceremoniału, rytuału, obrzędu czy religijnego symbolu jako nieredukowalnego zachowania, jako pierwotnego wyrazu życia. Nie są czymś dodanym, zewnętrznym, ozdoba. Sa przejawem życia, przebudzenia ducha: „Żadne zjawisko bowiem nie jest szczególnie tajemnicze samo przez się, lecz każde może stać się takim, i to właśnie jest charakterystyczne dla budzącego się ludzkiego ducha, że zjawisko ma dla niego znaczenie. Można by niemal powiedzieć, że człowiek jest ceremonialnym zwierzęciem” (Wittgenstein 1998: 20).

\section{/// B.}

Drugi przykład pokazuje, jak wewnętrzna logika pytań badawczych prowadzi do momentu, w którym w sposób niejako naturalny pojawia się pytanie o filozoficzne podstawy. W sposób niemal paradygmatyczny taka właśnie sytuacja ujawnia się w analizach przedstawionych przez Roberta Putnama w swojej pracy „E pluribus Unum”: wspólnota i różnorodność w XXI w. (Putnam 2007).

W tekście autor przedstawia rezultaty przeprowadzonego w $2000 \mathrm{r}$. ogromnego badania empirycznego (próba liczyła 30 tysięcy respondentów), którego celem było ustalenie, czy i jaki wpływ ma etniczne zróżnicowanie na społeczną solidarność, obywatelskie zaangażowanie i kapitał społeczny,

\footnotetext{
${ }^{11}$ „Gdy z opowiadaniem o królu-kapłanie Nemi zestawi się wyrażenie «majestat śmierci», widać, że stanowia jedno. [...]. Kto jest pod wrażeniem majestatu śmierci, może dać temu wyraz takim właśnie życiem".
} 
a przede wszystkim na zaufanie społeczne. Najważniejszy rezultat przeprowadzonych pogłębionych analiz autor przedstawia w następujący sposób:

Różnorodność nie wytwarza „złych stosunków rasowych” lub etnicznie zdeterminowanej międzygrupowej wrogości. Nasze badania wskazują raczej, że mieszkańcy zróżnicowanych [etnicznie] społeczności (diverse communities) przejawiają tendencję do wycofania się z życia społeczności (collective life), braku zaufania wobec sąsiadów niezależnie od koloru ich skóry, a nawet wycofania się z bliskich przyjaźni, oczekiwania najgorszego ze strony wspólnoty i jej liderów, rzadszego angażowania się $\mathrm{w}$ dobrowolne przedsięwzięcia, mniejszego łożenia na dobroczynność i rzadszego angażowania się w pracę nad projektami na rzecz konkretnej zbiorowości, rzadziej rejestrują się do wyborów, agituja wprawdzie bardziej za społecznymi reformami, ale nie wierza, by przyniosły one rzeczywistą zmianę, i lgną do siebie nieszczęśliwi przed ekranami telewizorów. Zauważmy, że ten wzór obejmuje postawy i zachowania, kapitał pomostowy i więziowy, prywatne i publiczne relacje. Różnorodność, przynajmniej na krótką metę, zdaje się ujawniać żółwia w każdym z nas (bring out the turtle in all of us) (Putnam 2007: 150-151).

Putnam zwraca uwagę, że w bardziej zróżnicowanych etnicznie środowiskach Amerykanie nie ufaja nie tylko ludziom, którzy wyglądają odmiennie od nich, ale także ludziom, którzy wyglądają dokładnie jak oni. Jeżeli jako biały mieszkam w zróżnicowanym środowisku, to nie tylko nie ufam czarnemu sąsiadowi, ale także sąsiadowi białemu jak ja. Ponadto reagowanie nieufnością jest niewrażliwe na wiele rodzajów społecznych kontekstów: na przykład różnorodność generuje bunkering („kulenie się w sobie") zarówno w zbiorowościach o wielkich nierównościach ekonomicznych, jak i w zbiorowościach relatywnie egalitarnych. Żeby wyeliminować możliwa pozorność związku między etniczna różnorodnością a społecznym wycofaniem się (termin Putnama: bunker down) i reagowaniem nieufnościa, Putnam bierze w analizach pod uwage kilkadziesiąt zmiennych i to zarówno na poziomie jednostkowym (wiek, wykształcenie, dochód itp.), jak i na poziomie kontekstu społecznego (wskaźnik ubóstwa, wskaźnik przestępstw w danej społeczności, gęstość zaludnienia, stopień zasiedziałości mieszkańców, stopień nierówności dochodowych itp.). Jednak wpływ różnorodności nie znika. Na odmienność reagujemy wycofaniem się ze sfery społecznej, „kuleniem się w sobie" (bunker down). Putnam posuwa się nawet do stwierdzenia, że reakcja na odmienność produkuje „paranoidalnego, pochłaniającego telewizję introwertyka".

Kontynuując logikę pytań badawczych Putnam poszerza zakres zmiennej niezależnej (wyjaśniającej). W oryginalnym schemacie badawczym zróżnicowanie (diversity) oznaczało zróżnicowanie etniczne społeczności miejsca zamieszkania respondenta. Putnam, powołując się na wcześniejsze badania, uogólnia „zróżnicowanie”. Ilustracje, które podaje, świadcza, 
że rozumie różnorodność bardzo szeroko. Wskazuje na przykład, że zróżnicowanie grupy pracowniczej wedle wieku, stopnia doświadczenia zawodowego, pochodzenia etnicznego i stażu pracy wiąże się z niższym poziomem spójności grupy, niższym zadowoleniem z pracy, większą fluktuacja. W północnym Pakistanie większe zróżnicowanie klanowe, religijne, polityczne tamtejszych społeczności wiąże się z niepowodzeniami kolektywnego dbania o infrastrukturę. Eksperymenty prowadzone w ramach teorii gier wykazały, że im bardziej różnią się od siebie gracze, tym większe prawdopodobieństwo, że zdradzą lub będą oszukiwać. Ale także wykorzystanie dokumentów historycznych dostarcza nowych możliwości uogólnienia zmiennej niezależnej. W okresie wojny secesyjnej w Armii Unii zaobserwowano, że w jednostkach o większym poziomie heterogeniczności (ze względu na wiek, miejsce zamieszkania, zawód żołnierzy) częstsze było zjawisko dezercji (Putnam 2007: 142-143).

Kiedy weźmiemy pod uwagę wszystkie analizy Putnama i ukierunkowanie jego pytań badawczych, z wielką siłą narzuca się jedno wrażenie, a mianowicie, że przebija z nich „metafizyczna melancholia”, coś niepokojącego - tysiące analiz i zawsze ten sam rezultat - na odmienność reagujemy „kuleniem się w sobie”. Nie ma wyjaśnienia ani zrozumienia tego zjawiska w obrębie socjologii, bo wzięcie pod uwagę wszystkich zmiennych społecznych nie usuwa efektu bunkering down. Putnam co prawda wspomina o różnych mechanizmach, począwszy od fizjologicznych, a skończywszy na politycznych, ale wszystkie proponowane przez niego wyjaśnienia tylko odsuwają problem, na który mógłby rzucić światło jedynie jakiś rodzaj antropologii filozoficznej. Putnam w swojej pracy dotarł do punktu, gdzie należałoby zadać innego rodzaju pytania, takie, które wymagają innego rodzaju kompetencji, których ani on, ani członkowie jego zespołu prawdopodobnie nie posiadali. Ale i tak ich praca stanowi wielkie osiagnięcie. Rzadko zdarza się, by analizy w naukach społecznych prowadziły aż tak daleko.

\section{/// 3.}

Związki filozofii i nauk społecznych maja też kontekst instytucjonalny. Instytucje stwarzaja pewne warunki możliwości, ale same w sobie niczego nie gwarantuja. Instytucjonalna, a nawet fizyczna bliskość filozofii i nauk społecznych, jak to się jeszcze czasem dzieje na uniwersytetach, nie musi oznaczać synergii.

Konkretne produktywne związki mogą być dziełem przypadku, a zdarza się, że wydaja się wręcz nieprawdopodobne w świetle naszej uprzedniej wiedzy. Tak było w przypadku Carla Schmitta i Waltera Benjamina. W grudniu 1930 r. Benjamin w liście do Schmitta zapowiada przesłanie mu 
swojej książki Źródła niemieckiej tragedii (Tranerspiel). W liście czytamy:

pisząc te słowa chciałbym nie tylko zapowiedzieć [swoją książke]][...], Natychmiast Pan zauważy, jak wiele moja książka zawdzięcza Panu tam, gdzie przedstawiam naukę o suwerenności w XVII w. Niech wolno mi będzie także powiedzieć, że także w Pana późniejszych pracach, przede wszystkim w Dyktaturze rozpoznałem potwierdzenie mojego sposobu badań w sferze filozofii sztuki poprzez Pana badania w sferze filozofii państwa. Jeżeli w trakcie lektury mojej książki stanie się to zrozumiałe, to zamiar jej przesłania Panu zostanie spełniony (Taubes 1987: 27).

Tego rodzaju nieoczekiwane inspiracje są możliwe dzięki specyficznej konstelacji okoliczności, które sa jedyne i nie powtarzają się nigdy. Takim specyficznym środowiskiem w XX w. była w latach 20. Republika Weimarska.

Same rozwiązania instytucjonalne nie gwarantują, że przyniosą jakaśs wartość dodana, wynikająca ze współpracy filozofa i badacza z dziedziny nauk społecznych. Można wskazać udane przykłady, kiedy struktury instytucjonalne (a zatem i odpowiednie praktyki), mające być miejscem pracy i spotkania badaczy z różnych dyscyplin, były tworzone świadomie. Przykładem sukcesu był niewatpliwie Instytut Frankfurcki z przełomu lat 20. i 30., gdzie filozofia, socjologia i psychologia wiele sobie wzajem zawdzięczały. Inny przykład to działalność Instytutu Maxa Plancka w Starnbergu w latach 1971-1983, kiedy to jego twórcy, Jürgenowi Habermasowi udało się stworzyć produktywne środowisko filozoficzno-społeczne. Rezultatem była jego książka Teoria dzৃiałania komunikacyjnego i wiele prac jego ówczesnych kolegów i wspólpracowników. Ten sukces udało mu się powtórzyć w latach 80., kiedy na uniwersytecie we Frankfurcie w oparciu o wielomilionowy grant stworzył zespół, badający rolę prawa we współczesnych demokratycznych systemach społecznych. Sam Habermas tak opisuje swoje doświadczenia:

W tym samym czasie [1986] Leibniz-Programm [...] umożliwił mi uruchomienie na pięć lat własnego projektu badawczego. Ten przypadkowy splot okoliczności dał mi sposobność do założenia zespołu pracującego nad zagadnieniami teorii prawa. Stworzył on niezwykle pobudzający i pouczający kontekst, w którym mogłem rozwinąć podjęte wówczas wątki. Odczuwałem tę współpracę, z której obok wielu innych publikacji powstała pewna seria monografii, jako szczególnie szczęśliwa. Bez twórczej pomocy kompetentnych współpracowników nie zdobyłbym się na odwagę, by podjąć projekt filozofii prawa; nie zdołałbym też przyswoić sobie tych argumentów i rozeznań, które były potrzebne do jego realizacji (Habermas 2005: 13-14).

Udanych przykładów jest zbyt mało, by starać się o uogólnienia. Nawet praktyka tzw. instytutów zaawansowanych studiów (advanced studies), starających się tworzyć szczególne warunki pracy badaczom z różnych dyscyplin, nie wytwarza środowisk, gdzie znacząco częściej dochodzi do przełomowych osiagnięć. 
Wspomniałem już, że w najbardziej ambitnych koncepcjach teoretycznych relacja „filozofia-nauka” ze względów logicznych nie może być ujmowana w kategoriach związku instrumentalnego - po prostu dlatego, że oba człony tej relacji sa współpierwotne. Stanowi to podstawowe ograniczenie świadomego (zaplanowanego) kształtowania praktyki. Dzieła Galileusza czy Hobbesa nie były rezultatem ,zastosowania” czy pouczenia ze strony filozofii, ponieważ one same były jednymi z pierwszych artykulacji nowej filozofii.

Jeżeli w ogóle w dzisiejszych instytucjonalnych strukturach nauki mają szanse zaistnieć możliwe relacje filozofii i nauk społecznych, to raczej w formach analizowanych w II części. Ale i tu napotykamy na dwie bariery. Pierwsza to bariera instytucjonalna. Mimo popularności wezwań do interdyscyplinarności specjalizacja badawcza i tematyczna wymusza na badaczach poruszanie się w obszarze ,istotnych publikacji”, „,ważnych konferencji” czy „kluczowych badaczy”. Twórcza praktyka badawcza nie wymaga zboczenia $z$ utartych szlaków, zatem normalnie nie ma powodu ani też motywacji, by zboczyć w kierunku filozofii. Wyjątkiem są sytuacje, kiedy pojawiają się trudności bądź impas, który może skłaniać do szukania inaczej i gdzie indziej. Druga bariera związana jest z samą filozofią jako specyficznym rodzajem wiedzy wraz z jej często bardzo technicznym aparatem pojęciowym. Badaczowi w naukach społecznych filozofia jawi się najczęściej jako autonomiczna, specjalistyczna, operująca wysoce technicznym językiem dyscyplina, której trudno wyjść poza własny dyskurs. Tak postrzegana i nauczana (jeżeli w ogóle) na użytek innych dyscyplin filozofia nie kształci ani motywacji do filozoficznych dociekań, ani wrażliwości na pewien typ pytań. Obu tym barierom próbuja zaradzić kreowane, najczęściej spontaniczne, różnorodne płaszczyzny spotkań - w postaci seminariów, projektów badawczych, pism, nieformalnych środowisk - stwarzające szanse filozofii i naukom na wspólny dyskurs i współobecność.

Bibliografia:

/// Czarnowski, S. 1958. Kultura religijna wiejskiego ludu polskiego. W: Tenże. Kultura. Warszawa: PWN.

/// Habermas, J. 2005. Faktyczność i obowiazywanie. Teoria dyskursu wobec ragadnien prawa i demokratycznego państwa prawnego. Przeł. Romaniuk A., Marszałek R. Warszawa: SCHOLAR.

/// Heidegger, M. 2001. Pytanie o rzecz. Przeł. Mizera J. Warszawa: Wydawnictwo KR. 
/// Mehring, R. 2009. Carl Schmitt, Aufstieg und Fall. Eine Biograpbie. München: Verlag C. H. Beck.

/// Peters, R.S., 1997. Introduction. W: Hobbes T. Leviathan. Oakeshott M. (red.). New York: A Touchstone Book.

/// Putnam, R.D. 2007. E pluribus Unum: Diversity and Community in the Twenty-first Century. The 2006 Johan Skytte Prize Lecture. „Scandinavian Political Studies" 30 (2).

/// Schmitt, C. 1923. Soziologie des Souveränitätsbegriffs und Politische Theologie. W: Palyi, M. (red.). Hauptprobleme der Soziologie. Erinnerungsgabe für Max Weber. München.

/// Schmitt, C. 2000. Teologia polityczna i inne pisma. Przeł. Cichocki, M.A. Kraków-Warszawa: Znak-Fundacja im. Stefana Batorego.

/// Schmitt, C. 2002. Das Zeitalter der Neutralisierungen. W: Der Begriff des Politischen. Text von 1932 mit einem Vorwort und drei Corollarien. Berlin: Duncker \& Humblot.

/// Schmitt, C. 2002a. Ex Captivitate Salus. Erfahrungen der Zeit 1945/47. Berlin: Duncker \& Humblot.

/// Schmitt, C. 2005. Die Einheit der Welt. W: Maschke, G. (red.). Frieden oder Påifismus? Berlin: Duncker \& Humblot.

/// Szawiel, T. 2008. Religijność ludowa: perspektyny spojrzenia. „Znak”3/2008. /// Taubes, J. 1987. Ad Carl Schmitt. Gegenstrebige Fügung. Berlin: Merve Verlag.

/// Taylor, Ch. 2007. A Secular Age. Cambridge: Harvard University Press. /// Taylor, Ch. 2001. Źródta podmiotowości. Narodziny tożsamości nowoczesnej. Warszawa: PWN.

/// Weber, M. 1994. Etyka protestancka a duch kapitalizmu. Przeł. Miziński J. Lublin: TEST.

/// Wittgenstein, L. 1998. Uwagi „,Ztotej Gałęi” Frazera. Przeł. Orzechowski A. Warszawa: Instytut Kultury.

\section{/// Abstrakt}

Zasadniczą tezą tekstu jest stwierdzenie, że obecność filozofii ujawnia się w naukach na zasadniczo dwóch poziomach. Pierwszy to paradygmatyczne osiagnięcia, najogólniejsze założenia teoretyczne oraz pojęciowość, która wyznacza przedmiot i problematykę badań. Przykładem takich osiagnięć jest nowożytna nauka (Galileusz), nowożytna filozofia społeczna (Hobbes), teorie procesów dziejowych (Max Weber, Carl Schmitt). Dla tego rodzaju najogólniejszych, paradygmatycznych osiagnięć charakterystyczna jest współpierwotność filozofii i nauki, co wyklucza możliwość planowania i kontroli „spotkania” filozofii z nauka. Drugi poziom dotyczy 
wewnętrznych problemów nauk społecznych, kiedy dane podejście lub teoria przestaja pełnić rolę skutecznych narzędzi badawczych, lub kiedy pytania badawcze wiodą do punktu, w którym nie istnieją odpowiedzi w ramach danego podejścia. Wówczas pojawia się miejsce na refleksję filozoficzna. W końcowej części wskazuje się możliwości i ograniczenia wiążące się ze świadomymi praktykami kształtowania obecności filozofii w naukach społecznych.

Słowa kluczowe: filozofia, socjologia, filozofia dziejów, rytuał, zaufanie.

\section{/// Abstract. Social Scienes and the Presence of Philosophy}

The main claim of the article is that what counts as the contribution of philosophy is present in the sciences (and humanities) on two levels. The first one can be described as the level of paradigmatic achievements. It includes the most general theoretical conditions, notions, and methods delimiting object of the science, what counts as a relevant fact and what are the fundamental research problems. Examples of such achievements are modern science (Gallilei), modern social philosophy (Hobbes) and philosophies of history (M. Weber, C. Schmitt). Characteristic of paradigmatic achievements is the instantaneousness (coincidence) of science and philosophy which precisely excludes the very possibility of a planned and controlled "encounter" of science and philosophy because at the very moment of the origin of the new paradigm "that" science and "that" philosophy do not yet exist (e.g. at the beginning of XVII century). The second level concerns the internal problems in sciences in moments when theories cease to be effective research tools or when the research questions are pushed beyond limits of existing approaches. And these are the situations which make place for philosophical reflection. A detailed analysis of two examples shows what exactly the contribution of philosophy might be in such a situation.

Keywords: philosophy, sociology, philosophy of history, ritual, trust. 